\title{
Performance Of Inherent Electrogens In Benthic Sediment Mud At Different pH Conditions \\ In Microbial Fuel Cell
}

ESJ Natural/Life/Medical Sciences

\section{Binjal Pradhan}

Bishop Macdonell Catholic High School, Clair Rd W, Guelph,Canada

\section{Ranjan Pradhan}

School of Engineering, University of Guelph, Guelph, Canada

Submitted: 14 August 2020

Accepted: 30 September 2020

Published: 31 October 2020

Corresponding author:

Ranjan Pradhan

DOI: 10.19044/esj.2020.v16n30p1

Copyright 2020 Pradhan et al.

Distributed under Creative Commons CC-BY 4.0 OPEN ACCESS

\section{Abstract}

Comparative measurement of electricity produced by inherent eletrogens in benthic mud that were maintained at different operating $\mathrm{pH}$ using microbial fuel cell was studied. A two-chamber microbial fuel cell model with proton exchange membrane was adopted for this study applying electrogene sourced from benthic mud collected from local lake and pond in Ontario. The objective of this study is to investigate the effects of different $\mathrm{pH}$ of 6,7 and 8 maintained within the anode cell in a microbial biofuel cell (MFC) containing microbial communities found in a benthic mud medium over 192 hours. The outcomes of the study demonstrated that in acidic conditions, there was an initial decrease in output whereas an alkaline condition allowed for the acclimatization and eventual increase of electric current and microbial activity of the study period. MFC operated at $\mathrm{pH} 7$ generated consistently higher electric power during the study duration exhibiting ideal conditions for the inherent exoelectrogenic bacteria. On average $249.8 \mathrm{mV}$ of electricity were measured from the MFC with $\mathrm{pH}$ 7. The average current density calculated to be 9.76 $( \pm 2.02) \times 10^{-5} \mu \mathrm{A} / \mathrm{cm}^{2}$. The average power density during the study period was calculated to be $2.49( \pm 0.77) \times 10^{-5}$ $\mu \mathrm{W} / \mathrm{cm}^{2}$

Subject: Biology, Bioenergy

Keywords: Microbial Biofuel Cell, Benthic Mud, Exoelectrogenic bacteria, Anoxic environment 


\section{Introduction}

The resiliency and diversity of microbes allow them to survive just about anywhere, including environments with extreme conditions such as different temperature, oxygen content, hydrogen ion $\left(\mathrm{H}^{+}\right)$concentrations or $\mathrm{pH}$ etc. With regard to microbial biofuel cell applications of microorganisms, traits like $\mathrm{pH}$ and respiration are important parameters for electrogens. Microorganism that thrive in neutral $\mathrm{pH}$ are known as neutrophils, while microbes that grow and multiply in $\mathrm{pH}$ less than 5.5 are called acidophiles, and those that flourish at $\mathrm{pH}$ higher than 9.5 are alkalophilic ${ }^{1}$. Many of these microbes are also able to live in anoxic environments while still performing cellular respiration efficiently. This is done with the help of the electron transport chain (ETC). The ETC is a mechanism that transfers de-energized electrons through various proteins to help create an electrochemical gradient. ATP synthase, an important protein in the ETC, then is able to use the gradient and create ATP for the cell to use as a source of energy ${ }^{2}$. The energy of the cell is thus produced by the movement of electrons that allows for the creation of a current that scientists can measure.

Specifically, exoelectrogenic bacteria that thrive in anoxic environments can transfer the electrons in their ETCs to a nearby conducting surface like an anode. The transfer of electrons outside of the ETC can be passed on via conductive pili or nano wires or be mediated involving redox mediators such as flavin and pyocyanin that are secreted naturally or introduced artificially with mediators like methylene blue and natural red. Extracellular electron transfer (EET) is the mechanism wherein microorganisms extract energy for growth and maintenance from their surroundings and transfer the resulting electrons to an anode to generate current. The efficiency of these electron transfer mechanisms is dependent not only on the redox potentials of the species involved, but also on the microbial oxidative metabolism that frees the electrons.

$\mathrm{pH}$ levels are known to drive bacterial community structure in sediments and similar is expected for electrogens ${ }^{3,4}$. Exoelectrogenic bacterial species composition in nature is known to change greatly depending on substrate also but their functionalities regarding electricity generation likely also depend on the $\mathrm{pH}$ for those substrate environments. Only a few exoelectrogenic bacteria from microbial biofuel cells have been directly isolated and studied ${ }^{5,6,7}$. Therefore there is a need to continue exploring dynamics of electrogens.

The potential of electrogens and their optimum environmental conditions can be studied using a microbial biofuel cells (MFC). Extracellular electron transfer (EET) to the anode is one of the most important mechanisms of MFC. These circuits are built to use microorganisms and detect electrical current from the metabolization of organic matter. MFCs provide accurate 
measurement for current produced by anoxic exoelectrogenic bacteria, specifically benthic sediment using two-chambers and a salt bridge as is adopted in this investigation ${ }^{8}$. Fuel cells can function as regenerating and organic sources of electrons while producing minimal waste. In an H-shaped MFC, the anode cell contains an electrode which is inserted into an organic substance-rich decomposing matter with a variety of exoelectrogenic bacteria. The electrode exposes a site for reduction and oxidation with the help of mediators in each cell and facilitates the collection and transfer of electrons in the circuit. The electrons move through the circuit to the cathode cell which is separated by a proton exchange membrane (PEM). The PEM allows for the movement of protons to the cathode without interfering with the pathway of the electrons. At the cathode, water is made through the reduction reaction with the water present in the cells and the electrons as an additional waste product to biofilm buildup in the anode ${ }^{9}$.

This study investigates the dynamics of electricity generation potential of natural sediment exoelectrogenic microbial communities existing in local cold climatic conditions using microbial fuel cells operated at different $\mathrm{pH}$ conditions. It is expected that various electron transfer mechanisms involved between existing microbes in benthic sediment and electrodes in microbial fuel cells in varying $\mathrm{pH}$ conditions will help for future enrichments and potential practical field applications using natural benthic exoelectrogens as a future in green energy. Specifically, this study will explore the effects of acidic, alkaline and natural $\mathrm{pH}$ conditions on the production of electric current in millivolts as a product of cellular respiration by exoelectrogenic bacteria in a microbial biofuel cell over a period of 192 hours.

\section{Materials and Method}

\subsection{Benthic Mud Sample:}

5L of benthic mud was collected in April of 2019 and mixed in equal proportion that was sampled from the bottom layer of sediment of a local lake - GPS coordinates (DD 43.510258, -80.194633) and from the floor of an outdoor fishpond - GPS coordinates (DD 43.499845, -80.199919). All nondecomposing matter was removed (i.e. branches, leaves, rocks etc.) and aseptically placed into a closed bucket for further use.

\subsection{Fuel Cells:}

The schematic diagram for the fuel cell designed and used for the study is presented in figure 1. Each individual fuel cell was assembled using a set of two plastic containers with airtight lids with a filling volume of $1.5 \mathrm{~L}$. The lids were drilled and attached to an airline tube and copper wire from an electrode. The wire and clear infeed tube connectors on the lid were secured and sealed with silicon glue. One of the containers labeled used as "anode" and the other one was labeled and used as "cathode". Additional holes were drilled to fit and 
attach cupper wire, venting tubes having a nonreturn valve. All wires and tubing inserted through the lids were secured with hot glue and silicone glue. A sandstone air bubbler was attached to the infeed tubes of cathode for continuous bubbling of air throughout the experiment. The infeed tube of anode was attached to a valve and kept close for any necessary feeding and sampling if needed. Both the containers were drilled with a 1.5-inch hole for fitting the proton exchange membrane tube. Both containers were attached using the 1.5-inch clear tube filled with agar-based proton exchange membrane sealed and securing through silicone glue.

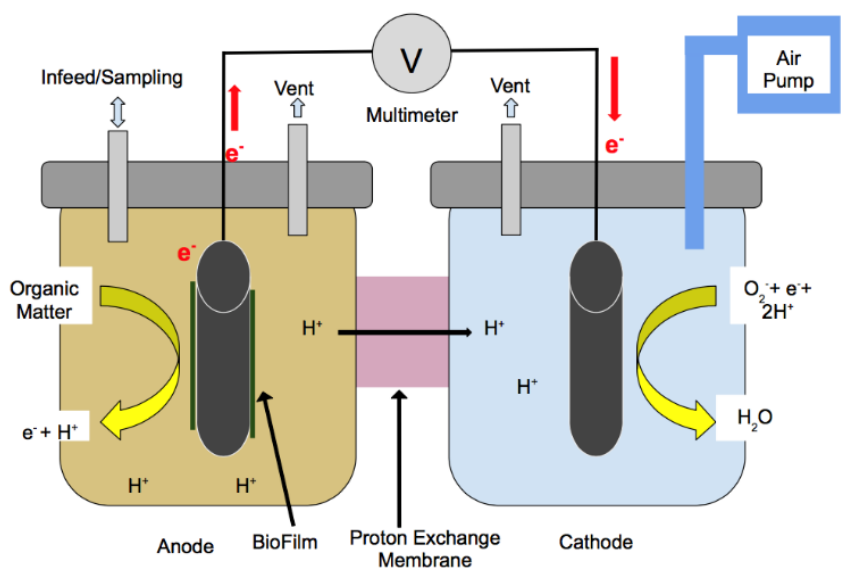

Figure 1 : Schematic diagram of the MFC design

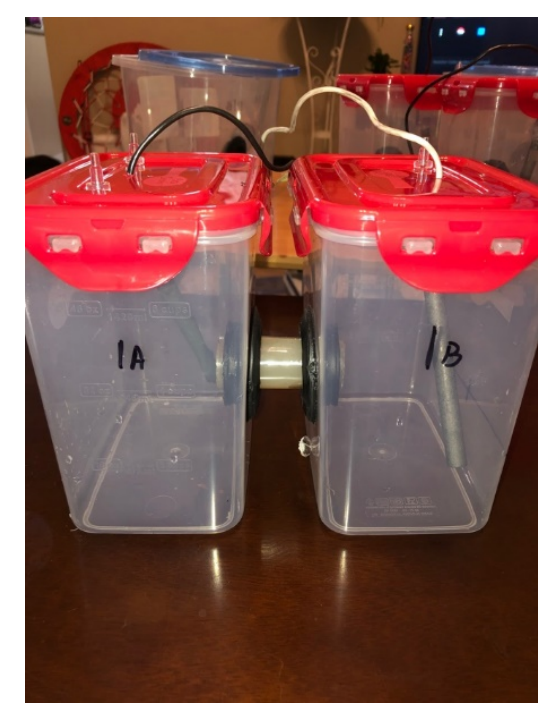

Figure 2 : Empty MFC Chambers with Electrodes 


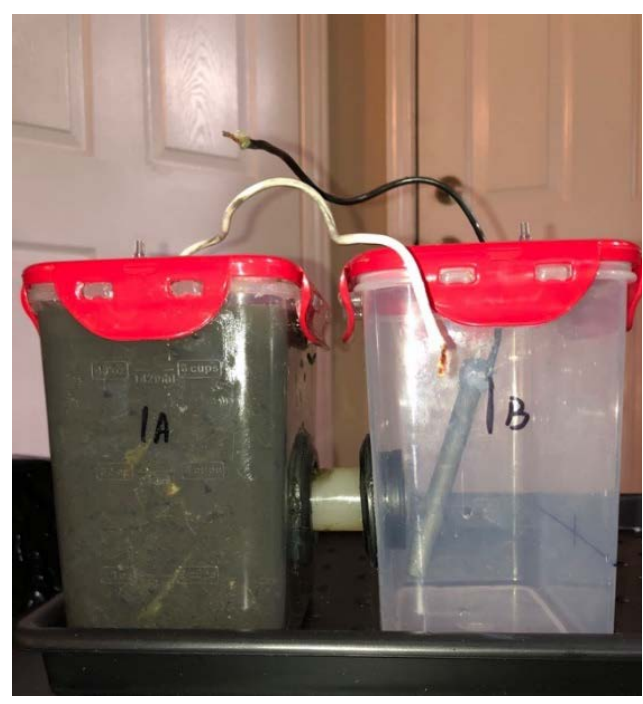

Figure 3 : Charged MFC Chambers with Electrodes

\subsection{Proton Exchange Membrane (PEM):}

Agar powder was dissolved by boiling to a strength of $4.4 \%$ and mixed to sodium chloride salt to a concentration of $20 \%$ solution in water. Solution was boiled further for two minutes and then removed to let cool to $37{ }^{\circ} \mathrm{C}$ $\pm 0.5^{\circ} \mathrm{C}$, where it was then poured into pipes of 1.5 inch in diameter and $4 \mathrm{~cm}$ in length with one end covered with plastic wrap. Tubes were let to cool and solidify in refrigerated condition ${ }^{10,11}$.

\subsection{Electrodes:}

Graphite rods of $10 \mathrm{mmX} 10 \mathrm{~cm}$ dimension with a measured geometrical surface area of $\sim 33 \mathrm{~cm}^{2}$ were used as electrodes. They were connected with copper wires by soft soldered with lead free solder and secured at the top end of the rod with metal clips.

\subsection{Experimental Set-up and calculations:}

All the anode chambers were filled with mixed mud samples to similar weight. The $\mathrm{pH}$ adjustments of the mud were stabilised using the respective buffer solutions. One molar buffer solution was added directly to the mud samples Sodium citrate buffer of $1 \mathrm{M}$ was used for $\mathrm{pH}$ 6, 1 molar buffer of $\mathrm{Na}_{2} \mathrm{CO}_{3}-\mathrm{NaHCO}_{3}$ buffer solution was used for maintaining $\mathrm{pH} 8$ were added and mixed until steady $\mathrm{pH}$ of 8 was achieved. Exposed ends of copper wires were connected to alligator clips and connected to digital multimeter to measure current every 24 hours for the remainder of the study period. The power generated is calculated based on equation -1(Eq. -1).

$P_{(\mathrm{W})}=V_{(\mathrm{V})} \times I_{(\mathrm{A})}$

(Eq. -1$)^{12}$ 
Where power $P$ in watts $(W)$ is equal to the voltage $V$ in volts $(V)$ times the current I in amps (A)

Power density and current density were calculated by dividing power and current by surface area of your electrode. Negative control of this MFC set-up was also simultaneously operated using distilled water only in both the chambers and potential difference was monitored.

\subsection{Experimental Design:}

All experiments were carried out in triplicates and the measurements were averaged of three independent readings in multimeters with $\mathrm{mV}$ and $\mu \mathrm{V}$ measuring limits. The independent variables in this study was the $\mathrm{pH}$ of the mixed benthic mud medium ${ }^{13}$. The $\mathrm{pH}$ of the anode cells was manipulated with acetic acid and sodium bicarbonate with a buffer. The dependent variable was the voltage that was measured with a millivolt multimeter representing electric current produced by the release of electrons as a result of microbial metabolism. Readings were taken during a study duration over a period of 192 hours. The control variables include but are not limited to the volume of benthic mud per anode cell, the creation of a medium made with mud from two sources (lake and fish pond), the same solution for the creation of the agarbased proton exchange membranes, use of sodium acetate as a buffer, temperature of mud storage and of experimental design, and the same materials are used to make electrodes (graphite rod) and copper wire circuits.

\section{Results and Discussion}

The MFC assembly setup for the study is as shown in the Figure 2 and 3. The negative control run of the MFC set-up did not measure any potential difference reading and is eliminated for any presentation of the reading. Figure 2 represent the empty cells with electrodes attached to the cells and figure 3 shows the cells charged with the sediment samples. The voltage measured at the terminal of the copper wire was an indicator of exoelectrogenic bacterial activity within the anodes in each $\mathrm{pH}$ condition. The $\mathrm{pH}$ of the anodes was intermittently tested aseptically to confirm that the $\mathrm{pH}$ conditions remained within their respective $\mathrm{pH}$ range till the end of the study period. Voltages measured during the study period for each test condition is presented in table 1 and in Figure 4, 5 and 6 for each condition. Table 2 presents the current measured for the fuel cell maintained at $\mathrm{pH}$ 7. The current measurement for other cells were inconsistent and unmeasurable and ignored for this study.

A combined trend of all the tests are presented in the figure 7. It is clear from the plots in Figure 4, 5 and 6 that the MFC with neutral $\mathrm{pH}$ of 7 demonstrate the steadiest electricity generation consistently while other two test conditions generated lower voltage and the trend differed significantly and 
contradicted to each other. The pH 6 condition showed a decreasing trend as shown in figure 4 and indicating that the mud medium in the anode cell was reaching minimal microbial activity, whereas in the $\mathrm{pH} 8$ condition showed an increasing trend as seen in figure 7 , indicating possible recovery of exoelectrogenic bacteria after 72 hours. As seen in the table 2 the current measured simultaneously in the MFC with $\mathrm{pH} 7$ represents a consistency during the study period.

\begin{tabular}{|l|l|l|l|l|l|l|l|l|l|}
\hline \multirow{2}{*}{$\begin{array}{l}\text { pH of } \\
\text { MFC }\end{array}$} & $0 \mathrm{~h}$ & $24 \mathrm{~h}$ & $48 \mathrm{~h}$ & $72 \mathrm{~h}$ & $96 \mathrm{~h}$ & $120 \mathrm{~h}$ & $144 \mathrm{~h}$ & $168 \mathrm{~h}$ & $192 \mathrm{~h}$ \\
\cline { 2 - 11 } $\mathrm{pH} \mathrm{6}$ & 283 & 254 & 2.1 & 32.1 & 2.3 & 76 & 42.1 & 42 & 39.1 \\
\hline $\mathrm{pH} 7$ & 139.5 & 307 & 285 & 249 & 263 & 256 & 278 & 219 & 252 \\
\hline pH 8 & 3.6 & 4.8 & 2.1 & 15.6 & 6.1 & 44.9 & 49.2 & 164.5 & 110.7 \\
\hline
\end{tabular}

Table 1. Voltages (mV) measured in each set of test conditions during the study period

$$
\text { Voltage Measured (mV) vs Time (h) for pH } 6
$$

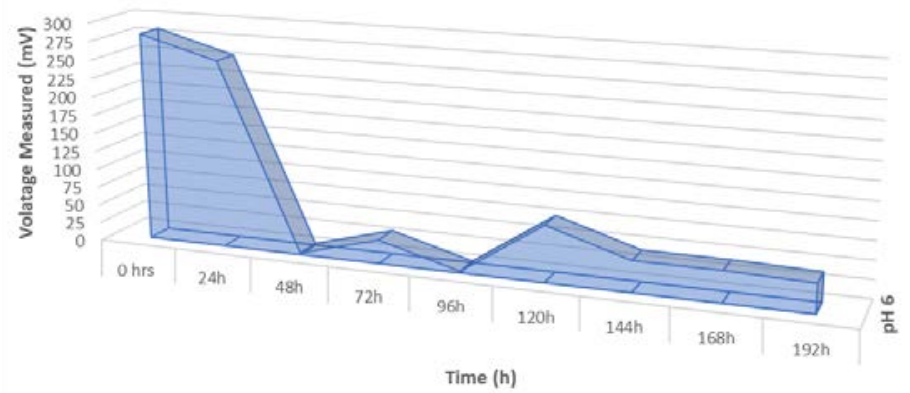

Figure 4. Graph of the voltage measured during 192 hours in MFC maintained at pH 6

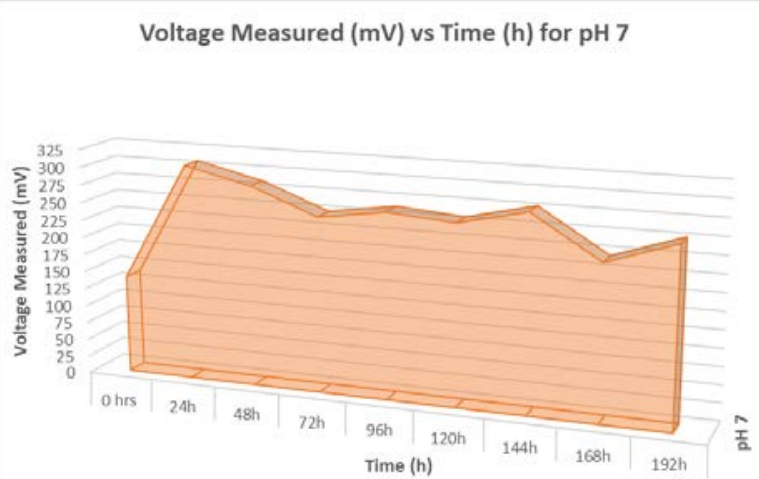

Figure 5. Graph of the voltage measured during 192 hours in MFC maintained at pH 7 


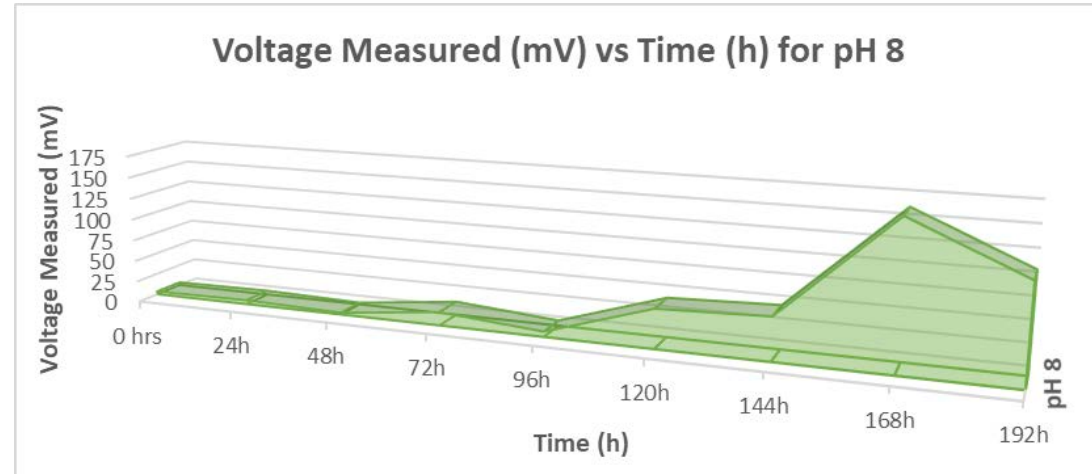

Figure 6. Graph of the voltage measured during 192 hours in MFC maintained at pH 8

\begin{tabular}{|c|c|c|c|c|c|c|c|c|c|c|}
\hline $\begin{array}{c}\text { Parameters } \\
\text { for } \mathrm{pH} 7 \\
\text { MFC } \\
\end{array}$ & $\mathrm{Oh}$ & $24 \mathrm{~h}$ & $48 \mathrm{~h}$ & $72 \mathrm{~h}$ & $96 \mathrm{~h}$ & $120 \mathrm{~h}$ & $144 \mathrm{~h}$ & $168 \mathrm{~h}$ & $192 \mathrm{~h}$ & $\begin{array}{l}\text { Average and } \\
\text { Standard } \\
\text { Deviation } \\
\text { (SD) }\end{array}$ \\
\hline $\begin{array}{c}\text { Measured } \\
\text { Potential } \\
\text { Difference } \\
(\mathrm{mV}) \\
\end{array}$ & 140 & 307 & 285 & 249 & 263 & 256 & 278 & 219 & 252 & $\begin{array}{c}250 \\
( \pm 48.3)\end{array}$ \\
\hline $\begin{array}{l}\text { Measured } \\
\text { Current } \\
(\mathrm{mA})\end{array}$ & $\begin{array}{c}2.0 \\
\mathrm{x} 10^{-3}\end{array}$ & $\begin{array}{c}3.0 \\
\times 10^{-3}\end{array}$ & $\begin{array}{c}3.0 \\
\mathrm{x} 10^{-3}\end{array}$ & $\begin{array}{c}3.0 \\
\mathrm{x} 10^{-3}\end{array}$ & $\begin{array}{c}4.0 \\
\mathrm{x} 10^{-3}\end{array}$ & $\begin{array}{c}4.0 \\
\times 10^{-3}\end{array}$ & $\begin{array}{c}4.0 \\
\mathrm{x} 10^{-3}\end{array}$ & $\begin{array}{c}3.0 \\
\times 10^{-3}\end{array}$ & $\begin{array}{c}3.0 \\
\times 10^{-3}\end{array}$ & $\begin{array}{c}3.22 \times 10^{-3} \\
\left( \pm 6.67 \times 10^{-4}\right)\end{array}$ \\
\hline $\begin{array}{c}\text { Current } \\
\text { Density } \\
\left(\mu \mathrm{A} / \mathrm{cm}^{2}\right)\end{array}$ & $\begin{array}{c}6.06 \\
\times 10^{-5}\end{array}$ & $\begin{array}{c}9.09 \\
\times 10^{-5}\end{array}$ & $\begin{array}{c}9.09 \\
\times 10^{-5}\end{array}$ & $\begin{array}{c}9.09 \\
x 10^{-5}\end{array}$ & $\begin{array}{l}1.21 \\
\mathrm{x} 10^{-4}\end{array}$ & $\begin{array}{c}1.21 \\
\mathrm{x} 10^{-4}\end{array}$ & $\begin{array}{l}1.21 \\
\mathrm{x} 10^{-4}\end{array}$ & $\begin{array}{c}9.09 \\
\times 10^{-5}\end{array}$ & $\begin{array}{c}9.09 \\
\times 10^{-5}\end{array}$ & $\begin{array}{c}9.76 \times 10^{-5} \\
\left( \pm 2.02 \times 10^{-5}\right)\end{array}$ \\
\hline $\begin{array}{l}\text { Calculated } \\
\text { Power } \\
(\mathrm{mW})\end{array}$ & $\begin{array}{c}2.79 \\
\times 10^{-4}\end{array}$ & $\begin{array}{l}9.21 \\
\times 10^{-4}\end{array}$ & $\begin{array}{l}8.55 \\
\times 10^{-4}\end{array}$ & $\begin{array}{l}7.47 \\
\times 10^{-4}\end{array}$ & $\begin{array}{l}1.05 \\
\mathrm{x} 10^{-3}\end{array}$ & $\begin{array}{c}1.02 \\
\times 10^{-3}\end{array}$ & $\begin{array}{l}1.11 \\
\mathrm{x} 10^{-3}\end{array}$ & $\begin{array}{c}6.57 \\
\times 10^{-4}\end{array}$ & $\begin{array}{c}7.56 \\
\times 10^{-4}\end{array}$ & $\begin{array}{c}8.23 \times 10^{-4} \\
\left( \pm 2.55 \times 10^{-4}\right)\end{array}$ \\
\hline $\begin{array}{l}\text { Calculated } \\
\text { Power } \\
\text { Density } \\
\left(\mu \mathrm{W} / \mathrm{cm}^{2}\right) \\
\end{array}$ & $\begin{array}{c}8.45 \\
\times 10^{-6}\end{array}$ & $\begin{array}{c}2.79 \\
\times 10^{-5}\end{array}$ & $\begin{array}{l}2.59 \\
\times 10^{-5}\end{array}$ & $\begin{array}{l}2.26 \\
x 10^{-5}\end{array}$ & $\begin{array}{c}3.19 \\
\times 10^{-5}\end{array}$ & $\begin{array}{c}3.10 \\
\times 10^{-5}\end{array}$ & $\begin{array}{l}3.37 \\
\mathrm{x} 10^{-5}\end{array}$ & $\begin{array}{c}1.99 \\
\times 10^{-5}\end{array}$ & $\begin{array}{c}2.29 \\
\times 10^{-5}\end{array}$ & $\begin{array}{c}2.49 \times 10^{-5} \\
\left( \pm 7.73 \times 10^{-6}\right)\end{array}$ \\
\hline
\end{tabular}

Table 2. Electric power generation parameters measured and calculated in the MFC operated at $\mathrm{pH} 7$ during the study period

Table 2 summarises the characteristics of power generation and performance of the MFC that was operated at $\mathrm{pH} 7$. The consistent power generation is demonstrated with measured current and calculated characteristic parameters for power. On average $249.8( \pm 48.3) \mathrm{mV}$ of potential difference were measured from the MFC with $\mathrm{pH} 7$ while average current produced was $3.22( \pm 0.667) \mathrm{mA}$. The average current density calculated to be $9.76( \pm 2.02) \times 10^{-5} \mu \mathrm{A} / \mathrm{cm}^{2}$. The average power density during the study period was calculated to be $2.49( \pm 0.773) \times 10^{-5} \mu \mathrm{W} / \mathrm{cm}^{2}$. The maximum generated voltage, current, power and surface power density are observed to be consistent during the study duration. The pattern calculated 
characteristic of change in current generation and power generation is presented in figure 8 and follow similar trend for both. The power measured was open circuit power since the external resistance is not used. The power generated is likely due to internal impedance, which seemed to be very high. High impedance of substrate may be because of improper mixing of substrate and water as reported by Liu et. al. ${ }^{14}$.

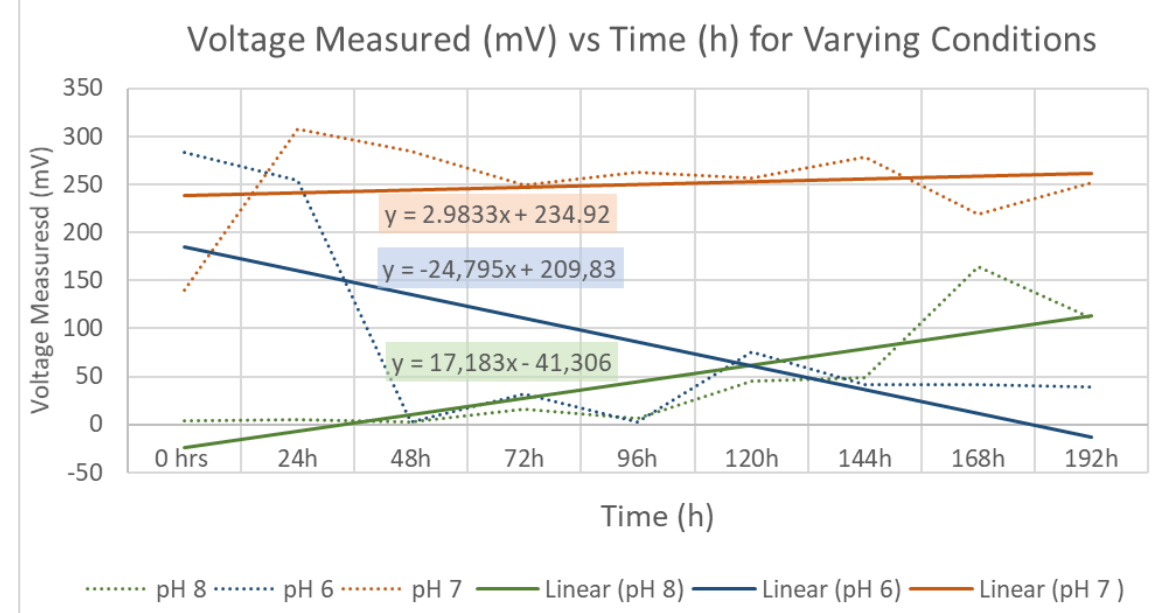

Figure 7. Trend and rate of changes of the voltage measured in the MFC's for 192 hour period

Figure 7 shows the trend lines of voltage generation in the MFCs throughout the experiment and gradients for the trends are presented. For the pH 7 condition, the voltages remained between 200-310 mV士 1 following the first 24 hours for the remainder of the experiment. The gradient of the trendline was found to be 2.983, which indicates that the microbial activity was relatively constant. For the $\mathrm{pH} 6$ condition, there was a significant decrease in voltage after the first 48 hours., after which the voltage levelled off and remained in a lower voltage range. The trendline had a gradient of -24.795 and displays a steep decrease in activity of exoelectrogenic bacteria. For the $\mathrm{pH} 8$ condition, there was a gradual increase in voltages after 120 hours. The trendline had a gradient of 17.138 and displays a steep decrease in activity of exoelectrogenic bacteria. The basic condition initially had extremely low activity and voltage measured, indicating minimal electron transfer and cellular activity. However, at approximately 96 hours, voltage increased and continued for the remainder of the experiment. This may indicate possible acclimatization of the exoelectrogenic bacteria to support the increasing gradient of the trendline. 

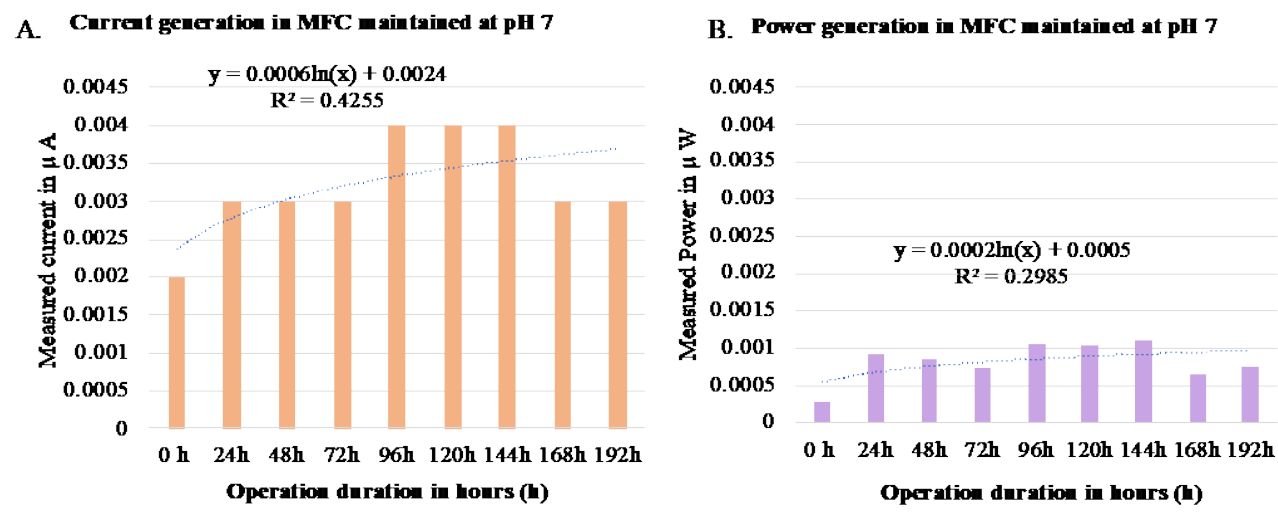

Figure 8. Current generation (A) and power generation (B) trends in the MFC's operated at pH 7 during 192hour period

\section{Conclusion}

The study demonstrated that the operating $\mathrm{pH}$ environment have significant impact on the activity and electron transfer in native exoelectrogenic bacteria samples in two chamber MFCs. Alkaline environments eventually lead to positive effects on the transfer of electrons in electricity producing microbes and may need further detailed investigation to realise any potential for isolating related electrogens that may have missed to be isolated and identified by researchers. Benthic mud of cold climatic natural environments of Ontario my harbour unique organism that can maintain constant cellular respiration and help electric current production of future in MFC's for potential field application. Influence of $\mathrm{pH}$ in the performance of bacteria communities identified in this study due to effect on the activity of exoelectrogenic bacteria and diversity of the microbial communities in the source of the electrogen used in MFCs have been reported and supported by various other studies reported in literature ${ }^{15,16}$.

The results of this investigation draw attention to the characteristics of electrogens from cold climatic benthic mud, optimal performance of the MFC at $\mathrm{pH} 7$ and the potential power generation characteristics of the system and samples studied. This study may further be extrapolated for the use of microbial fuel cells as a contributor to green energy. Scientific literature widely agrees that there is a general lack of clarity and professional research into the effectiveness of various variables of the construction MFC is necessary to determine the most efficient design and use of microbes as should be carried out by other researchers $17,18,19,20$. Various forms of bioenergy are the future resource for ever increasing sustainable energy demands ${ }^{21,22}$. Further details investigation on MFC is likely to strengthen this approach. 


\section{Acknowledgments}

This research was supported by Shrimp Canada, Guelph, Ontario, Canada and Bishop Macdonell CHS, Guelph, Ontario, Canada.

\section{References:}

1. Simčič, T., \& Brancelj, A. (2006). Effects of $\mathrm{pH}$ on electron transport system (ETS) activity and oxygen consumption in Gammarus fossarum, Asellus aquaticus and Niphargus sphagnicolus. Freshwater Biology, 51(4), 686-694. https://doi.org/10.1111/j.13652427.2006.01522.x

2. Electron Transport Chain | BioNinja. (n.d.). https://ib.bioninja.com.au/higher-level/topic-8-metabolismcell/untitled/electron-transport-chain.html

3. Jin, Q., \& Kirk, M. F. (2018). pH as a primary control in environmental microbiology: 1. thermodynamic perspective. Frontiers in Environmental Science, 6(MAY), 1-15. https://doi.org/10.3389/fenvs.2018.00021

4. Shen, C., Xiong, J., Zhang, H., Feng, Y., Lin, X., Li, X., Liang, W., \& Chu, H. (2013). Soil pH drives the spatial distribution of bacterial communities along elevation on Changbai Mountain. Soil Biology and Biochemistry, 57(July 2012), 204-211. https://doi.org/10.1016/j.soilbio.2012.07.013

5. Sun, Y., Zuo, J., Cui, L., Deng, Q., \& Dang, Y. (2010). Diversity of microbes and potential exoelectrogenic bacteria on anode surface in microbial fuel cells. Journal of General and Applied Microbiology, 56(1), 19-29. https://doi.org/10.2323/jgam.56.19

6. Zuo, Y., Xing, D., Regan, J. M., \& Logan, B. E. (2008). Isolation of the exoelectrogenic bacterium Ochrobactrum anthropi YZ-1 by using a U-tube microbial fuel cell. Applied and Environmental Microbiology, 74(10), https://doi.org/10.1128/AEM.02732-07

7. D. V, A., \& T. M, O. (2017). Generating Electricity Using Microbial Fuel Cell Powered by Benthic Mud Collected From Two Locations in Akure, Nigeria. European Scientific Journal, ESJ, 13(18), 242. https://doi.org/10.19044/esj.2017.v13n18p242

8. JM, K., DN, M., JM, M., FB, M., \& GN, K. (2017). Microbial Fuel Cells: Influence of External Resistors on Power, Current and Power Density. Journal of Thermodynamics \& Catalysis, 08(01), 1-5. https://doi.org/10.4172/2157-7544.1000182

9. Du, Z., Li, H., \& Gu, T. (2007). A state of the art review on microbial fuel cells: A promising technology for wastewater treatment and 
bioenergy. Biotechnology Advances, 25(5), 464-482. https://doi.org/10.1016/j.biotechadv.2007.05.004

10. FLogan, B. E., Hamelers, B., Rozendal, R., Schröder, U., Keller, J., Freguia, S., Aelterman, P., Verstraete, W., \& Rabaey, K. (2006). Microbial fuel cells: Methodology and technology. Environmental Science and Technology, 40(17), 5181-5192. https://doi.org/10.1021/es0605016

11. Ghasemi, M., Daud, W. R. W., Ismail, A. F., Jafari, Y., Ismail, M., Mayahi, A., \& Othman, J. (2013). Simultaneous wastewater treatment and electricity generation by microbial fuel cell: Performance comparison and cost investigation of using Nafion 117 and SPEEK as separators. Desalination, 325, 1-6. https://doi.org/https://doi.org/10.1016/j.desal.2013.06.013

12. Parkash, A. (2016). Characterization of Generated Voltage, Current, Power and Power Density from Cow Dung Using Double Chambered Microbial Fuel Cell. Journal of Physical Chemistry \& Biophysics, 6(2). https://doi.org/10.4172/2161-0398.1000208

13. Cho, S., Kim, M. \& Lee, Y. Effect of $\mathrm{pH}$ on soil bacterial diversity. $\mathrm{j}$ ecology environ 40, 10 (2016). https://doi.org/10.1186/s41610-0160004-1

14. Liu, S., Ren, H., Shen, L., Lou, L., Tian, G., Zheng, P., \& Hu, B. (2015). pH levels drive bacterial community structure in the Qiantang River as determined by 454 pyrosequencing. Frontiers in Microbiology, 6(MAR), 1-7. https://doi.org/10.3389/fmicb.2015.00285

15. Logan, B. E., Hamelers, B., Rozendal, R., Schröder, U., Keller, J., Freguia, S., Aelterman, P., Verstraete, W., \& Rabaey, K. (2006). Microbial fuel cells: Methodology and technology. Environmental Science and Technology, 40(17), 5181-5192. https://doi.org/10.1021/es0605016

16. Xia, C., Zhang, D., Pedrycz, W., Zhu, Y., \& Guo, Y. (2018). Models for Microbial Fuel Cells: A critical review. Journal of Power Sources, 373(October 2017),

119-131. https://doi.org/10.1016/j.jpowsour.2017.11.001

17. Logan, B. E., Hamelers, B., Rozendal, R., Schröder, U., Keller, J., Freguia, S., Aelterman, P., Verstraete, W., \& Rabaey, K. (2006). Microbial fuel cells: Methodology and technology. Environmental Science and Technology, 40(17), 5181-5192. https://doi.org/10.1021/es0605016

18. Du, Z., Li, H., \& Gu, T. (2007). A state of the art review on microbial fuel cells: A promising technology for wastewater treatment and 
19. bioenergy. Biotechnology Advances, 25(5), 464-482. https://doi.org/10.1016/j.biotechadv.2007.05.004

20. Pradhan, R. R., Pradhan, R. R., Das, S., Dubey, B., \& Dutta, A. (2017). Bioenergy Combined with Carbon Capture Potential by Microalgae at Flue Gas-Based Carbon Sequestration Plant of NALCO as Accelerated Carbon Sink. Green Energy and Technology. Springer, 231-244. https://doi.org/10.1007/978-981-10-3352-0_16

21. Tamakloe, R. Y., Donkor, M. K. E., \& Singh, K. (2017). Fabrication and Study of Power- Output of MultiChamber Microbial Fuel Cells (Mfcs) With Clay as Ion Exchange Partition. European Scientific Journal, ESJ, 13(30), 173. https://doi.org/10.19044/esj.2017.v13n30p173

22. Zhao, C. E., Gai, P., Song, R., Chen, Y., Zhang, J., \& Zhu, J. J. (2017). Nanostructured material-based biofuel cells: Recent

23. advances and future prospects. Chemical Society Reviews, 46(5), 1545-1564. https://doi.org/10.1039/c6cs00044d

24. Okekunle, P. O., Itabiyi, O. E., Olafimihan, E. O., Alayande, I. O., Najeemdeen, M. O., Adisa, O. A., \& Popoola, A. B. (2019). Effect of Chicken Type and Reactor Temperature on Biofuel Yields from Pyrolysis of Poultry Litter. European Scientific Journal, ESJ, 15(3), 61. https://doi.org/10.19044/esj.2019.v15n3p6 